\title{
Antioxidative and Antihyaluronidase Activities of Some Constituents from the Aerial Part of Daucus carota
}

\author{
Masateru ONO, ${ }^{1}$ Chikako MASUOKA, ${ }^{1}$ Takemi TANAKA, ${ }^{1}$ Yasuyuki ITO ${ }^{1}$ and Toshihiro NOHARA ${ }^{2}$ \\ ${ }^{1}$ School of Agriculture, Kyushu Tokai University, Choyo 5435, Aso, Kumamoto 869-1404, Japan \\ ${ }^{2}$ Faculty of Pharmaceutical Sciences, Kumamoto University, Oe-honmachi 5-1, Kumamoto 862-0973, Japan
}

Received April 19, 2001; Accepted August 29, 2001

\begin{abstract}
The methanol extract of the aerial part of Daucus carota var. sativus showed a stronger antioxidative activity than the standard synthetic antioxidant, 3-tert-butyl-4-hydroxyanisole (BHA). From this extract, five known compounds,

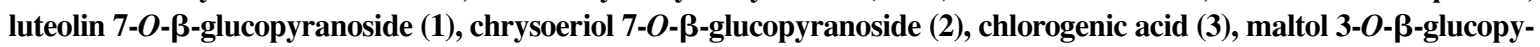
ranoside (4) and benzyl $\beta$-glucopyranoside (5) were isolated. Among them, when 1-4 were investigated for their antioxidative activity using the ferric thiocyanate method, 1-3 indicated an antioxidative activity. The scavenging effect of 1-4 on the stable free radical, 1,1-diphenyl-2-picrylhydrazyl was also examined. Compounds 1 and 3 showed a scavenging effect. In addition, 1-3 were assayed for their inhibitory effects on the activation of inactive hyaluronidase induced by compound $48 / 80$. All tested compounds showed this effect.
\end{abstract}

Keywords: Daucus carota, antioxidative activity, ferric thiocyanate method, radical scavenger, antihyaluronidase activity

Antioxidants function to protect against lipid peroxidation which causes the rancidity of fats and oil in food. They can also protect the human body from harmful free radicals which damage unsaturated fatty acids in cell membranes, DNA and enzymes. This damage is believed to induce aging and several diseases, such as cancer, inflammation and atherosclerosis (Yagi, 1987; Yoshikawa et al., 1994). It was also reported that some antiallergic drugs showed antioxidative activities due to scavenging of superoxide radicals (Yoshikawa et al., 1989). Since hyaluronidase is related to histamine release from mast cells, the inhibitory effect of this enzyme is one of the indexes of the antitype I allergy (Sakamoto et al., 1980; Kakegawa et al., 1985)

During the course of our studies on natural antioxidants (Ono et al., 1995, 1997, 1998, 1999, 2000; Masuoka et al., 1997), the methanol $(\mathrm{MeOH})$ extract of the aerial part of Daucus carota var. sativus (Umbelliferae), which is used as a foodstuff, showed a stronger antioxidative activity than the standard synthetic antioxidant, 3-tert-butyl-4-hydroxyanisole (BHA) using the ferric thiocyanate method. The present paper describes the separation and structure elucidation of five compounds, luteolin 7-O- $\beta$-glucopyranoside (1), chrysoeriol 7-O- $\beta$-glucopyranoside (2), chlorogenic acid (3), maltol 3-O- $\beta$-glucopyranoside (4) and benzyl $\beta$-glucopyranoside (5) from the $\mathrm{MeOH}$ extract and the antioxidative activities of 1-4. The inhibitory effect of 1-3 on the activation of inactive hyaluronidase induced by compound 48/80 (Maeda et al., 1990) is also dealt with.

\section{Materials}

$\alpha$-Tocopherol, BHA and 1,1-diphenyl-2-picrylhydrazyl (DP$\mathrm{PH}$ ) were obtained from Nacalai Tesque, Inc. (Kyoto). Linoleic acid was purchased from Tokyo Kasei Kogyo Co. (Tokyo).

E-mail mono@as-1.ktokai-u.ac.jp
Hyaluronidase (from bovine testis, Type IV-S, 880 units/mg, Lot 94H8000), compound 48/80 and disodium chromoglycate (DSCG) were purchased from Sigma Chemical Co.(St. Louis, MO). Tranilast was obtained from Tocris Cookson, Ltd. (Avonmouth, Bristol, UK). The aerial part of Daucus carota var. sativus (Kouyo) was collected at Kagoshima prefecture in Japan in April 1995. Luteolin (6) [ ${ }^{1} \mathrm{H}-\mathrm{NMR}$ (in dimethylsulfoxide (DMSO)- $d_{6}$, $500 \mathrm{MHz}) \delta$ : $7.41\left(1 \mathrm{H}, \mathrm{dd}, J=2.5,8.0 \mathrm{~Hz}, \mathrm{H}-6^{\prime}\right), 7.40(1 \mathrm{H}, \mathrm{d}$, $\left.J=2.5 \mathrm{~Hz}, \mathrm{H}-2^{\prime}\right), 6.89\left(1 \mathrm{H}, \mathrm{d}, J=8.0 \mathrm{~Hz}, \mathrm{H}-5^{\prime}\right), 6.66(1 \mathrm{H}, \mathrm{s}, \mathrm{H}-3)$, 6.45 (1H, d, J=2.0 Hz, H-8), 6.19 (1H, d, J=2.0 Hz, H-6), (Harborne, 1986)] was isolated from the fruit of Vitex tifolia $\mathrm{L}$.

\section{Methods}

Proton $\left({ }^{1} \mathrm{H}\right)$ - and carbon-13 $\left({ }^{13} \mathrm{C}\right)$-nuclear magnetic resonance (NMR) spectra were recorded using a JEOL JNM-GX-400 and a JEOL alpha 500 spectrometer (JEOL, Tokyo), and chemical shifts were given on a $\delta(\mathrm{ppm})$ scale with tetramethylsilane (TMS) as an internal standard. The abbreviations used are as follows: s, singlet; br s, broad singlet; d, doublet; dd, double-doublet; br d, broad doublet; ddd, double-double-doublet; t, triplet; $\mathrm{m}$, multiplet. Optical rotations were measured with a JASCO DTP-1000 KUY digital polarimeter (JASCO, Tokyo). Visible absorptions were measured with a Shimadzu UV-140-02 spectrometer (Shimadzu, Kyoto). Column chromatography (CC) was carried out over silica gel 60 (Merck, Art. 9385; Merck, Darmstadt, Germany), Diaion HP20 and MCI gel CHP 20P (both from Mitsubishi Chemical Industries Co., Ltd., Tokyo) and Sephadex LH20 (Pharmacia Fine Chemicals, Uppsala, Sweden).

Extraction and isolation The cut fresh aerial part $(2.00$ $\mathrm{kg}$ ) of Daucus carota var. sativus was soaked in $\mathrm{MeOH}(4.0 \mathrm{l}$ ) for 23 days at room temperature. The $\mathrm{MeOH}$ extract (71.6 g) was partitioned between hexane $(0.6 l)$ and $\mathrm{MeOH}(0.4 l)$. The $\mathrm{MeOH}$ soluble fraction (fr.) was subjected to Diaion HP $20 \mathrm{CC}$ 
(solv., $\mathrm{H}_{2} \mathrm{O}, 60 \% \mathrm{MeOH}, \mathrm{MeOH}$, acetone) to afford fr. 1 (58.2 g), fr. $2(5.3 \mathrm{~g})$, fr. $3(2.1 \mathrm{~g})$ and fr. $4(0.2 \mathrm{~g})$. Fraction $2(1.8 \mathrm{~g})$ was chromtographed over Diaion HP 20 with a gradient of $\mathrm{H}_{2} \mathrm{O}$ $\mathrm{MeOH}(20 \% \rightarrow 65 \%)$ to afford $1(139 \mathrm{mg})$ and frs. 5-15. Fraction $6(330 \mathrm{mg})$ was subjected to silica gel $\mathrm{CC}$ eluted with $\mathrm{CHCl}_{3}: \mathrm{MeOH}: \mathrm{H}_{2} \mathrm{O}(6: 4: 1)$ to give frs. 16-19. Fraction 16 (28 $\mathrm{mg}$ ) was subjected to Sephadex LH-20 CC eluted with $60 \%$ $\mathrm{MeOH}$ to afford 4 (20 mg). Fraction 19 was chromatographed over MCI gel CHP 20P eluted with $\mathrm{MeOH}$ to furnish 3 (47 mg). Fraction 9 (234 mg) was chromatographed over silica gel with a gradient of $\mathrm{CHCl}_{3}: \mathrm{MeOH}: \mathrm{H}_{2} \mathrm{O}(14: 2: 0.1 \rightarrow 6: 4: 1)$ to give 5 (6 $\mathrm{mg})$. Fraction $13(82 \mathrm{mg}$ ) was subjected to Sephadex LH-20 CC eluted with $\mathrm{MeOH}$ to give 2 (20 mg).

Luteolin 7-O- $\beta$-glucopyranoside (1): yellow powder, $[\alpha]_{\mathrm{D}}^{24}$ $-49.0^{\circ}$ ( $c=1.1$, DMSO). ${ }^{1} \mathrm{H}-\mathrm{NMR}$ (in DMSO- $d_{6}, 500 \mathrm{MHz}$ ) $\delta$ : $12.99(1 \mathrm{H}, \mathrm{s}, \mathrm{OH}-5$ of aglycone $(\mathrm{Ag})), 10.00(1 \mathrm{H}, \mathrm{br}$ s, OH of $\mathrm{Ag}), 9.42\left(1 \mathrm{H}\right.$, br s, OH of Ag), $7.46\left(1 \mathrm{H}, \mathrm{dd}, J=2.0,8.5 \mathrm{~Hz}, \mathrm{H}-6^{\prime}\right.$ of $\mathrm{Ag}), 7.43\left(1 \mathrm{H}, \mathrm{d}, J=2.0 \mathrm{~Hz}, \mathrm{H}-2^{\prime}\right.$ of $\left.\mathrm{Ag}\right), 6.92(1 \mathrm{H}, \mathrm{d}, J=8.5$ $\mathrm{Hz}, \mathrm{H}-5^{\prime}$ of $\left.\mathrm{Ag}\right), 6.80(1 \mathrm{H}, \mathrm{d}, J=2.0 \mathrm{~Hz}, \mathrm{H}-8$ of Ag), $6.75(1 \mathrm{H}, \mathrm{s}$, H-3 of Ag), $6.46(1 \mathrm{H}, \mathrm{d}, J=2.0 \mathrm{~Hz}, \mathrm{H}-6$ of $\mathrm{Ag}), 5.09(1 \mathrm{H}, \mathrm{d}$, $J=7.3 \mathrm{~Hz}, \mathrm{H}-1$ of glucose (Glc)). ${ }^{13} \mathrm{C}-\mathrm{NMR}$ (in DMSO- $d_{6}, 100$ $\mathrm{MHz}$ ) : 181.9 (C-4 of Ag), 164.5 (C-2 of Ag), 163.0 (C-7 of $\mathrm{Ag}$ ), 161.1 (C-5 of Ag), 157.0 (C-9 of Ag), 149.9 (C-4' of Ag), 145.8 (C-3' of Ag), 121.4 (C-1' of Ag), 119.2 (C-6' of Ag), 116.0 (C-5' of Ag), 113.6 (C-2' of Ag), 105.3 (C-10 of Ag), 103.2 (C-3 of Ag), 99.9 (C-1 of Glc), 99.5 (C-6 of Ag), 94.8 (C-8 of Ag), 77.2 (C-3 of Glc or C-5 of Glc), 76.4 (C-5 of Glc or C-3 of Glc), 73.1 (C-2 of Glc), 69.6 (C-4 of Glc), 60.6 (C-6 of Glc).

Chrysoeriol 7- $O$ - $\beta$-glucopyranoside (2): yellow powder, $[\alpha]_{\mathrm{D}}^{24}$ $-33.3^{\circ}$ ( $c=0.7$, DMSO). ${ }^{1} \mathrm{H}-\mathrm{NMR}$ (in DMSO- $d_{6}, 500 \mathrm{MHz}$ ) $\delta$ : $12.95\left(1 \mathrm{H}\right.$, br s, OH-5 of Ag), $7.59\left(1 \mathrm{H}, \mathrm{d}, J=8.0 \mathrm{~Hz}, \mathrm{H}-6^{\prime}\right.$ of $\mathrm{Ag}), 7.59$ (1H, s, H-2' of Ag), $6.97(1 \mathrm{H}, \mathrm{s}, \mathrm{H}-3 \mathrm{of} \mathrm{Ag}), 6.96(1 \mathrm{H}$, d, $J=8.0 \mathrm{~Hz}, \mathrm{H}-5^{\prime}$ of Ag), $6.87(1 \mathrm{H}, \mathrm{d}, J=2.5 \mathrm{~Hz}, \mathrm{H}-8$ of Ag), 6.46 $(1 \mathrm{H}, \mathrm{d}, J=2.5 \mathrm{~Hz}, \mathrm{H}-6$ of Ag), $5.07(1 \mathrm{H}, \mathrm{d}, J=7.3 \mathrm{~Hz}, \mathrm{H}-1$ of Glc), $3.90\left(3 \mathrm{H}, \mathrm{s}, \mathrm{OCH}_{3}\right) .{ }^{13} \mathrm{C}-\mathrm{NMR}$ (in DMSO-d $d_{6}, 100 \mathrm{MHz}$ ) $\delta$ : 182.1 (C-4 of Ag), 164.2 (C-2 of Ag), 163.0 (C-7 of Ag), 161.1 (C-5 of Ag), 157.0 (C-9 of Ag), 150.9 (C-3' of Ag), 148.1 (C-4' of $\mathrm{Ag}), 121.4\left(\mathrm{C}-1^{\prime}\right.$ of $\left.\mathrm{Ag}\right), 120.6\left(\mathrm{C}-6^{\prime}\right.$ of $\left.\mathrm{Ag}\right), 115.8\left(\mathrm{C}-5^{\prime}\right.$ of $\mathrm{Ag}), 110.3$ (C-2' of Ag), 105.4 (C-10 of Ag), 103.5 (C-3 of Ag), 100.0 (C-1 of Glc), 99.5 (C-6 of Ag), 95.1 (C-8 of Ag), 77.3 (C-3 of Glc or C-5 of Glc), 76.5 (C-5 of Glc or C-3 of Glc), 73.1 (C-2 of Glc), 69.6 (C-4 of Glc), 60.7 (C-6 of Glc), $56.0\left(\mathrm{OCH}_{3}\right)$.

Chlorogenic acid (3): white powder, $[\alpha]_{\mathrm{D}}^{26}-33.9^{\circ}(c=1.7$, $\mathrm{MeOH}$ ). ${ }^{1} \mathrm{H}-\mathrm{NMR}$ (in $\mathrm{MeOH}-d_{4}, 500 \mathrm{MHz}$ ) $\delta: 7.56(1 \mathrm{H}, \mathrm{d}$, $J=16.0 \mathrm{~Hz}, \mathrm{H}-7$ of caffeic acid (Caf)), $7.04(1 \mathrm{H}$, br s, H-2 of Caf), 6.93 (1H, br d, $J=8.0 \mathrm{~Hz}, \mathrm{H}-6$ of Caf), 6.77 (1H, d, $J=8.0$ $\mathrm{Hz}, \mathrm{H}-5$ of Caf), 6.26 (1H, d, $J=16.0 \mathrm{~Hz}, \mathrm{H}-8$ of Caf), $5.35(1 \mathrm{H}$, $\mathrm{m}, \mathrm{H}-3$ of quinic acid (Qui)), 4.20 (1H, br s, H-5 of Qui), 3.73 $\left(1 \mathrm{H}\right.$, br d, $J=6.7 \mathrm{~Hz}, \mathrm{H}-4$ of Qui), ${ }^{1} \mathrm{H}-\mathrm{NMR}$ (in acetone- $d_{6}, 500$ $\mathrm{MHz}) \delta$ : $7.59(1 \mathrm{H}, \mathrm{d}, J=16.0 \mathrm{~Hz}, \mathrm{H}-7$ of Caf $), 7.18(1 \mathrm{H}, \mathrm{d}, J=2.0$ $\mathrm{Hz}, \mathrm{H}-2$ of Caf), 7.02 (1H, dd, J=2.0, $8.0 \mathrm{~Hz}, \mathrm{H}-6$ of Caf), 6.88 $(1 \mathrm{H}, \mathrm{d}, J=8.0 \mathrm{~Hz}, \mathrm{H}-5$ of Caf), $6.32(1 \mathrm{H}, \mathrm{d}, J=16.0 \mathrm{~Hz}, \mathrm{H}-8$ of Caf), 5.38 (1H, ddd, $J=5.0,9.0,10.5 \mathrm{~Hz}, \mathrm{H}-3$ of Qui), $4.27(1 \mathrm{H}$, ddd, $J=3.0,3.0,3.0 \mathrm{~Hz}, \mathrm{H}-5$ of Qui), $3.80(1 \mathrm{H}, \mathrm{dd}, J=3.0,9.0$ $\mathrm{Hz}, \mathrm{H}-4$ of Qui), 2.28 (1H, br d like, $J=13.0 \mathrm{~Hz}, \mathrm{H}-2 \mathrm{a}$ of Qui), $2.14\left(2 \mathrm{H}, \mathrm{m}, \mathrm{H}_{2}-6\right.$ of Qui), $2.04(1 \mathrm{H}, \mathrm{dd}, J=10.5,13.0 \mathrm{~Hz}, \mathrm{H}-2 \mathrm{~b}$ of Qui). ${ }^{13} \mathrm{C}-\mathrm{NMR}$ (in $\left.\mathrm{MeOH}-d_{4}, 100 \mathrm{MHz}\right) \delta$ : 178.4 (C-7 of Qui), 168.9 (C-9 of Caf), 149.5 (C-4 of Caf), 147.1 (C-7 of Caf), 146.8 (C-3 of Caf), 127.8 (C-1 of Caf), 123.0 (C-6 of Caf), 116.5
(C-5 of Caf), 115.3 (C-2 of Caf), 115.2 (C-8 of Caf), 77.3 (C-1 of Qui), 73.9 (C-4 of Qui or C-5 of Qui or C-3 of Qui), 72.1 (C-4 of Qui or C-5 of Qui or C-3 of Qui), 71.9 (C-4 of Qui or C-5 of Qui or C-3 of Qui), 39.4 (C-2 of Qui), 38.3 (C-6 of Qui).

Maltol 3-O- $\beta$-glucopyranoside (4): white powder, $[\alpha]_{\mathrm{D}}^{26}$ $-40.8^{\circ}(c=2.1, \mathrm{MeOH}) .{ }^{1} \mathrm{H}-\mathrm{NMR}$ (in MeOH- $\left.d_{4}, 500 \mathrm{MHz}\right) \delta$ : $8.00(1 \mathrm{H}, \mathrm{d}, J=5.5 \mathrm{~Hz}, \mathrm{H}-6$ of Ag), $6.45(1 \mathrm{H}, \mathrm{d}, J=5.5 \mathrm{~Hz}, \mathrm{H}-5$ of $\mathrm{Ag}), 4.80(1 \mathrm{H}, \mathrm{d}, J=7.5 \mathrm{~Hz}, \mathrm{H}-1$ of Glc), $3.82(1 \mathrm{H}, \mathrm{dd}, J=2.0$, $12.0 \mathrm{~Hz}, \mathrm{H}-6 \mathrm{a}$ of Glc), $3.67(1 \mathrm{H}, \mathrm{dd}, J=5.0,12.0 \mathrm{~Hz}, \mathrm{H}-6 \mathrm{~b}$ of Glc), 3.40 (2H, H-3 of Glc and H-4 of Glc), 3.34 (1H, dd, $J=7.5$, $9.5 \mathrm{~Hz}, \mathrm{H}-2$ of Glc), 3.26 (1H, m, H-5 of Glc), 2.46 (3H, s, $\mathrm{H}_{3}-7$ of Ag). ${ }^{13} \mathrm{C}-\mathrm{NMR}$ (in $\mathrm{MeOH}-d_{4}, 100 \mathrm{MHz}$ ) $\delta$ : 177.2 (C-4 of Ag), 164.6 (C-3 of Ag), 157.2 (C-6 of Ag), 143.7 (C-2 of Ag), 117.3 (C-5 of Ag), 105.5 (C-1 of Glc), 78.5 (C-3 of Glc or C-5 of Glc), 78.0 (C-5 of Glc or C-3 of Glc), 75.4 (C-2 of Glc), 71.1 (C-4 of Glc), 62.5 (C-6 of Glc), 15.8 (C-7 of Ag).

Benzyl $\beta$-glucopyranoside (5): white powder, $[\alpha]_{\mathrm{D}}^{27}-39.2^{\circ}$ $(c=0.7, \mathrm{MeOH}) .{ }^{1} \mathrm{H}-\mathrm{NMR}$ (in $\left.\mathrm{MeOH}-d_{4}, 500 \mathrm{MHz}\right) \delta: 7.41(2 \mathrm{H}$, $\mathrm{d}, J=7.5 \mathrm{~Hz}, \mathrm{H}-2$ of $\mathrm{Ag}$ and $\mathrm{H}-6$ of $\mathrm{Ag}), 7.32(2 \mathrm{H}, \mathrm{dd}, J=7.5,7.5$ $\mathrm{Hz}, \mathrm{H}-3$ of $\mathrm{Ag}$ and $\mathrm{H}-5$ of $\mathrm{Ag}), 7.27(1 \mathrm{H}, \mathrm{t}, J=7.5 \mathrm{~Hz}, \mathrm{H}-4$ of $\mathrm{Ag}), 4.93(1 \mathrm{H}, \mathrm{d}, J=11.5 \mathrm{~Hz}, \mathrm{H}-7 \mathrm{a}$ of $\mathrm{Ag}), 4.67(1 \mathrm{H}, \mathrm{d}, J=11.5$ $\mathrm{Hz}, \mathrm{H}-7 \mathrm{~b}$ of Ag), 4.35 (1H, d, J=7.5 Hz, H-1 of Glc), $3.89(1 \mathrm{H}$, $\mathrm{dd}, J=2.0,11.5 \mathrm{~Hz}, \mathrm{H}-6 \mathrm{a}$ of Glc), $3.69(1 \mathrm{H}, \mathrm{dd}, J=5.5,11.5 \mathrm{~Hz}$, $\mathrm{H}-6 \mathrm{~b}$ of Glc). ${ }^{13} \mathrm{C}-\mathrm{NMR}$ (in MeOH- $d_{4}, 150 \mathrm{MHz}$ ) $\delta: 139.1$ (C-1 of Ag), 129.3 ((C-2 of Ag and C-6 of Ag) or (C-3 of Ag and C-5 of Ag)), 129.2 ((C-2 of Ag and C-6 of Ag) or (C-3 of Ag and C-5 of Ag)), 128.7 (C-4 of Ag), 103.3 (C-1 of Glc), 78.1 (C-3 of Glc), 78.1 (C-5 of Glc), 75.2 (C-2 of Glc), 71.8 (C-7 of Ag), 71.8 (C-4 of Glc), 62.9 (C-6 of Glc).

Antioxidative assay by the ferric thiocyanate method Antioxidative assay of the test sample was measured using the previously described ferric thiocyanate method (Ono et al., 2000; Kikuzaki \& Nakatani, 1993). A mixture of $2.51 \%$ linoleic acid ethanol $(\mathrm{EtOH})$ solution $(1.00 \mathrm{ml}), 0.05 \mathrm{M}$ phosohate buffer $(\mathrm{pH}$ $7.0,2.00 \mathrm{ml})$ and $\mathrm{H}_{2} \mathrm{O}(1.00 \mathrm{ml})$ was added to the $\mathrm{EtOH}$ solution $(1.00 \mathrm{ml})$ of each sample in a vial with a cap and placed in the dark at $40^{\circ} \mathrm{C}$ to accelerate the oxidation. At intervals during incubation, this assay solution $(0.05 \mathrm{ml})$ was diluted with $75 \% \mathrm{EtOH}$ $(4.85 \mathrm{ml})$, which was followed by adding $30 \%$ ammonium thiocyanate $(0.05 \mathrm{ml})$. Precisely $3 \mathrm{~min}$ after the addition of $0.02 \mathrm{M}$ ferrous chloride in $3.5 \%$ hydrochloric acid $(0.05 \mathrm{ml})$ to the reaction mixture, the absorbance due to the developed red color was measured at $500 \mathrm{~nm}$. The control sample was prepared from the mixture containing all ingredients except a test sample. $\alpha$-Tocopherol and BHA were used as standard samples.

Assay of scavenging effect on DPPH We applied the method of Uchiyama et al. (1968) slightly modified. EtOH solution $(1.00 \mathrm{ml})$ of each tested sample was added to a mixture of $0.1 \mathrm{M}$ acetate buffer ( $\mathrm{pH} 5.5,1.00 \mathrm{ml})$ and $0.5 \mathrm{mM}$ DPPH EtOH solution $(0.50 \mathrm{ml})$ in a test tube and left to stand at room temperature for $30 \mathrm{~min}$. The absorbance of the resulting solution was measured at $517 \mathrm{~nm}$. The control sample was prepared from the mixture containing all ingredients except the test sample. $\alpha$ Tocopherol was used as standard sample.

Assay of antihyaluronidase activity Test samples were dissolved in DMSO, and each solution was diluted with $0.1 \mathrm{M}$ acetate buffer ( $\mathrm{pH} 4.0$ ) to ten volumes. Hyaluronidase, hyaluronic acid potassium salt and compound 48/80 were dissolved with the same buffer. Hyaluronidase activity was determined by the 
method of Maeda et al. (1990). Antiallergic agents, DSCG and tranilast, which indicated strong antihyaluronidase activity (Maeda et al.,1990), were used as standard samples.

\section{Results and Discussion}

The aerial part of Daucus carota var. sativus was extracted with $\mathrm{MeOH}$ at room temperature. This extract, which indicated a stronger antioxidative activity than BHA using linoleic acid as the substrate in the ferric thiocyanate method at a concentration of $0.02 \%$, was partitioned between hexane and $\mathrm{MeOH}$. The $\mathrm{MeOH}$ soluble fraction showed a stronger antioxidative activity than the hexane soluble fraction, and was fractionated by repeated column chromatographies (Diaion HP20, MCI gel CHP 20P, silica gel, Sephadex LH20) to afford five compounds (1-5).

Structure elucidation of $\mathbf{1 - 5}$ Compounds $\mathbf{1}-\mathbf{5}$ were identified as luteolin 7-O- $\beta$-glucopyranoside (Harborne \& Mabry, 1982; Harborne, 1994), chrysoeriol 7-O- $\beta$-glucopyranoside (Harborne \& Mabry, 1982; Harborne, 1994; Tomás et al., 1986), chlorogenic acid (Nishizawa et al., 1988), maltol 3-O- $\beta$-glucopyranoside (Hori et al., 1987) and benzyl $\beta$-glucopyranoside (Miyase et al., 1987), respectively, on the bases of spectral data (Fig. 1). As far as we know, this is the first example of the isolation of 1-5 from the aerial part of Daucus carota var. sativus.

Antioxidative effect of compounds 1-4 The antioxidative activities of 1-4 and luteolin (6) which is an aglycone of $\mathbf{1}$, were investigated in the same manner as that used for the $\mathrm{MeOH}$ extract. All these compounds, except $\mathbf{4}$, showed a stronger anti-
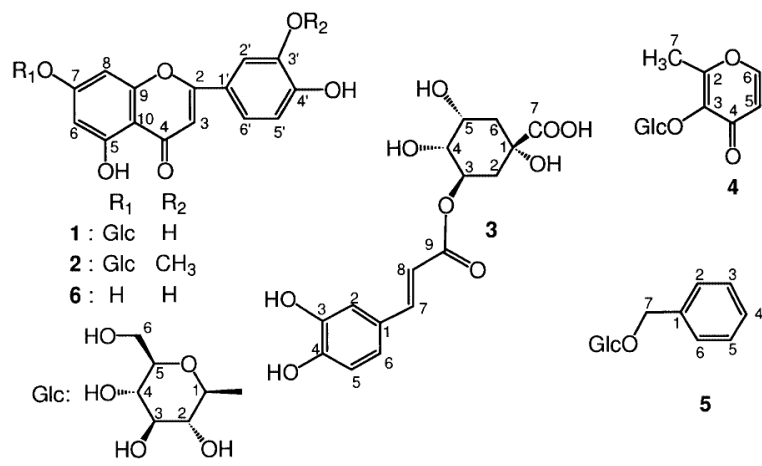

Fig. 1. Structures of $1-6$

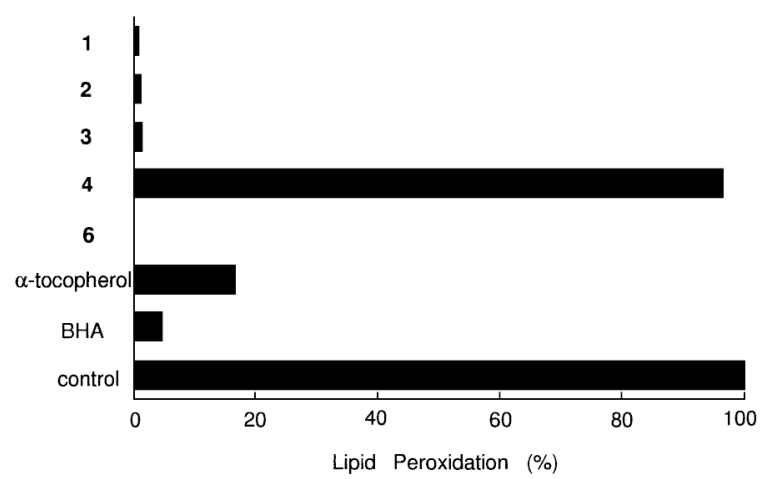

Fig. 2. Antioxidative activity of $\mathbf{1 - 4}, \mathbf{6}, \alpha$-tocopherol and BHA after 5 days of lipid peroxidation. The final concentration of each sample tested was $0.5 \mathrm{~mm}$. A control containing no added samples or standards on its values represents $100 \%$ lipid peroxidation.

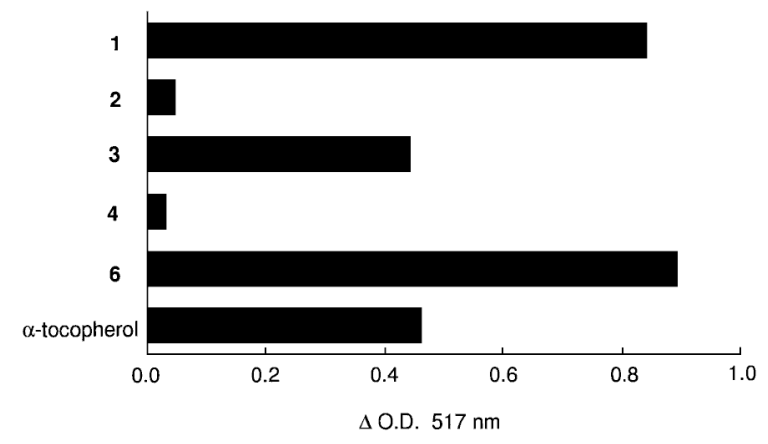

Fig. 3. DPPH radical scavenging effect of 1-4, 6 and $\alpha$-tocopherol. The final concentration of each sample tested was $0.02 \mathrm{mM}$. $\Delta$ O. D.=O.D. of control at $517 \mathrm{~nm}(1.120)-$ O.D. of sample. DPPH; $0.1 \mathrm{~mm}$.

oxidative activity than that of BHA at a concentration of $0.5 \mathrm{mM}$ (Fig. 2). Moreover, the scavenging effect of $\mathbf{1 - 4}$, and $\mathbf{6}$ on the stable free radical DPPH was examined. Compounds 1, 3 and 6 showed the scavenging effect (Fig. 3), which the effects of $\mathbf{1}$ and 6 being stronger than that of $\alpha$-tocopherol at a concentration of $0.02 \mathrm{~mm}$. Compounds $\mathbf{1}-\mathbf{3}$ were therefore considered to be the antioxidative principles of the $\mathrm{MeOH}$ extract of the aerial part of Daucus carota var. sativus. Recently Yokozawa et al. (1998) reported that catechyl (3,4-dihydroxyphenyl) group in the B-ring of flavonoid skeleton is most important for DPPH radical scavenging effect, and our previous study (Ono et al., 2000) bore out this structure-activity relationship. The result in this investigation also supported this relationship, because $\mathbf{1}$ exhibited stronger DPPH radical scavenging effect than that of $\mathbf{2}$. We earlier reported (Ono et al., 2000) the DPPH radical scavenging effect of five dicaffeoyl quinic acid derivatives whose effects were stronger than that ( $\Delta$ O. D. 0.212$)$ of 3 at a concentration of 0.01 $\mathrm{mm}$. Therefore, the radical scavenging effect of caffeoyl quinic acid derivatives might depend on the number of caffeoyl residue. Chrologenic acid and its isomer were lately reported as the antioxidants in prune (Prunus domestica L.) by Nakatani et al. (2000). Moreover, the antioxidative activity of chlorogenic acid using fluorescence spectroscopy was reported by Wang et al. (1999).

Antihyaluronidase activities of 1-3 Compounds 1-3 and 6 were assayed for their inhibitory effects on the activation of inactive hyaluronidase induced by compound 48/80 (Maeda et al., 1990). Compounds 1 and $\mathbf{3}$ showed almost the same inhibitory activity as that of tranilast, and the activity of $\mathbf{2}$ was one half

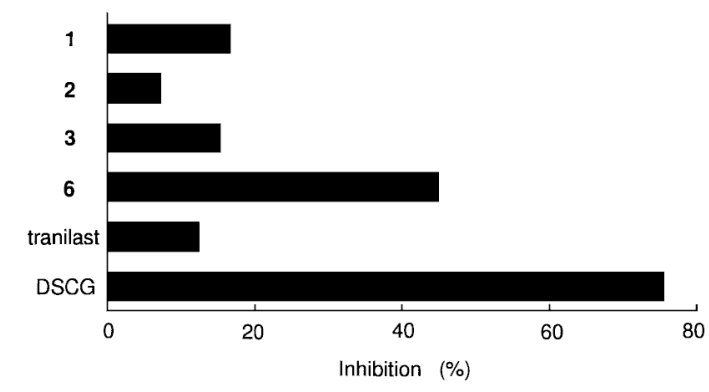

Fig. 4. Inhibitory effect of 1-3, 6, tranilast and DSCG on the activation of hyaluronidase. The final concentration of each sample tested was $0.2 \mathrm{~mm}$. 
that of 1 at a concentration of $0.2 \mathrm{mM}$ (Fig. 4). Therefore, it was presumed that the catechyl group showed a stronger hyaluronidase inhibitory activity than the guiacyl (4-hydroxy-3-methoxyphenyl) group. Structure-activity relationship of flavonoids as inhibitors of hyaluronidase was reported by Kuppusamy et al. (1990). In their report, it was stated that the inhibitory activity of flavonoid glycosides is less than those of the corresponding aglycone. Our result in this study supported their report, because 6 exhibited stronger inhibitory activity than did $\mathbf{1}$. The inhibitory effects of chlorogenic acid on the histamine release from the mast cells which induced compound 48/80 (Kimura et al., 1985) and 5-lipoxygenase (Nishizawa et al., 1988) were previously reported. Therefore, chlorogenic acid may be effective as an antiallergic drug.

Acknowledgments We express our appreciation to Mr. K. Takeda of Kumamoto University for his measurement of the NMR spectra. This study was supported in part by a Grant-in-Aid for Scientific Research (C) (No. 12672081) from Japan Society for the Promotion of Science, and by the General Research Organization of Tokai University.

\section{References}

Harborne, J.B. and Mabry, T.J. (1982). In "The Flavonoids: Advances in Research.” ed. by Chapman and Hall, N.Y., p. 73, p. 77.

Harborne, J.B. (1994). In "The Flavonoids: Advances in Research since 1986," ed. by Chapman and Hall, N.Y., p. 450.

Hori, K., Satake, T., Saiki, Y., Murakami, T. and Chen, C. (1987). Chemical and chemotaxonomical studies of filices. LXIX. The novel coumarins of Macrothelypteris torresiana CHING var. calvata HolTT. (=M. oligophlebia CHING). Yakugaku Zasshi, 107, 491-494 (in Japanese).

Kakegawa, H., Matsumoto, H. and Satoh, T. (1985). Activation of hyaluronidase by metallic salts and compound $48 / 80$, and inhibitory effect of antiallergic agents on hyaluronidase. Chem. Pharm. Bull., 33, 642-646.

Kikuzaki, H. and Nakatani, N. (1993). Antioxidant effects of some ginger constituents. J. Food Sci., 58, 1407-1410.

Kimura, Y., Okuda, H., Okuda, T., Hatano, T., Agata, I. and Arichi, S. (1985). Studies on the activities of tannins and related compounds from medicinal plants and drugs. VI. Inhibitory effects of caffeoylquinic acids on histamine release from rat peritoneal mast cells. Chem. Pharm. Bull., 33, 690-696.

Kuppusamy, U.R., Khoo, H.E. and Das, N.P. (1990). Structure-activity studies of flavonoids as inhibitors of hyaluronidase. Biochem. Pharmacol., 40, 397-401.

Maeda, Y., Yamamoto, M., Masui, T., Sugiyama, K., Yokota, M., Nakagomi, K., Tanaka, H., Takahashi, I., Kobayashi, T. and Kobayashi, E. (1990). Inhibitory effect of tea extracts on hyaluronidase (Studies on anti-allergic activity in tea. II). Shokuhin Eiseigaku Zasshi, 31, 233-237 (in Japanese).

Masuoka, C., Ono, M., Ito, Y. and Nohara, T. (1997). Antioxidative constituents from the aerial part of Piper elongatum VAHL.. Food Sci Technol. Int. Tokyo, 3, 285-289.

Miyase, T., Ueno, A., Takizawa, N., Kobayashi, H. and Karasawa, H. (1987). Studies on the glycosides of Epimedium grandiflorum MORR. var. thunbergianum (MIQ.) NAKAI. I. Chem. Pharm. Bull., 35, 1109-1117.

Nakatani, N., Kayano, S., Kikuzaki, H., Sumino, K., Katagiri, K. and Mitani, T. (2000). Identification, quantitative determination, and antioxidative activities of chlorogenic acid isomers in prune (Prunus domestica L.). J. Agric. Food Chem., 48, 5512-5516.

Nishizawa, M., Izuhara, R., Kaneko, K., Koshihara, Y. and Fujimoto, Y. (1988). 5-Lipoxygenase inhibitors isolated from Gardeniae Fructus. Chem. Pharm. Bull., 36, 87-95.

Ono, M., Ito, Y., Masuoka, C., Koga, H. and Nohara, T. (1995). Antioxidative constituents from Dendrobii herba (stems of Dendrobium spp.). Food Sci. Technol. Int., 1, 115-120.

Ono, M., Masuoka, C., Ito, Y., Niiho, Y., Kinjo, J. and Nohara, T. (1997). Antioxidative and antihyaluronidase activities of some constituents from Foeniculi Fructus (fruit of Foeniculum vulgare Miller). Food Sci. Technol. Int. Tokyo, 3, 53-55.

Ono, M., Masuoka, C., Ito, Y. and Nohara, T. (1998). Antioxidative constituents from Viticis trifoliae Fructus (fruit of Vitex rotundifolia L.). Food Sci. Technol. Int. Tokyo, 4, 9-13.

Ono, M., Yamamoto, M., Masuoka, C., Ito, Y., Yamashita, M. and Nohara, T. (1999). Diterpenes from Fruits of Vitex rotundifolia. J. Nat. Prod., 62, 1532-1537.

Ono, M., Masuoka, C., Odake, Y., Ikegashira, S., Ito, Y. and Nohara, T. (2000). Antioxidative constituents from Tessaria integrifolia. Food Sci. Technol. Res, 6, 106-114.

Sakamoto, K., Nagai, H. and Koda, A. (1980). Role of hyaluronidase in immediate hypersensitivity reaction. Immunopharmacology, 2, $139-146$.

Tomás, F., Nieto, J.L., Barberán, F.A.T. and Ferreres, F. (1986). Flavonoids from Phlomis lychnitys. Phytochemistry, 25, 1253-1254.

Uchiyama, M., Suzuki, Y and Fukuzawa, K. (1968). Biochemical studies of physiological function of tocopheronolactone.1. Yakugaku Zasshi, 88, 678-683 (in Japanese).

Wang, H., Nair, M.G., Strasburg, G., M., Booren, A.M. and Gray, J.I. (1999) Novel antioxidant compounds from Tart Cherries (Prunus cerasus). J. Nat. Prod., 62, 86-88.

Yagi, K. (1987). Lipid peroxides and human disease. Chem. Phys. Lipids, 45, 337-341.

Yokozawa, T., Chen, C.P., Dong, E., Tanaka, T., Nonaka, G. and Nishioka, I., (1998). Study on the inhibitory effect of tannins and flavonoids against the 1,1-diphenyl-2-picrylhydrazyl radical. Biochem. Pharmacol., 56, 213-222.

Yoshikawa, T., Naito, Y., Takahashi, S., Tanigawa, T., Oyamada, H., Ueda, S., Takemura, T., Sugino, S. and Kondo, M. (1989). Influences of antiallergic drugs on superoxide generation from the hypoxanthine-xanthine oxidase system or polymorphonuclear leukocytes. Arerugi, 38, 486-492 (in Japanese).

Yoshikawa, T., Naito, Y. and Kondo, M. (1994). "Antioxidants (Free Radicals and Biological Defense).” ed. by Niki, E., Shimasaki, H. and Mino, M. Japan Scientific Societies Press, Tokyo (in Japanese). 